\title{
Reproductive Health in Hajj Worship (Relationship of Husband and Wife Sexuality and Menstrual Management)
}

\author{
Umul Hidayati ${ }^{1}$, Fauziah ${ }^{2}$ \\ \{hidayatikuncoro@yahoo.com ${ }^{1}$, fauziahmz2606@gmail.com² \\ Research and Development Centers, Religious Community Guidance and Religious Services ${ }^{1}$, \\ Research and Development Agencies, and Training Education, the Ministry of Religion ${ }^{2}$
}

\begin{abstract}
The research entitled "Reproductive Health in Hajj (Husband and Wife Sexuality Relationship and Menstrual Management)" which was conducted in 2020, aims to find out how to fulfill the reproductive health rights of Indonesian pilgrims of productive age, including sexual relations between husband and wife and menstrual management. The research was conducted using qualitative methods, with phenomenological, sociological and psychological approaches. The technique of collecting data was through in-depth interviews and documentation studies, using the inductive analysis method. The results showed that in general the rights of pilgrims had been fulfilled, especially in terms of knowledge and understanding of Reproductive Health, including the issue of husband and wife sexual relations during the pilgrimage, maintaining the health of reproductive organs and managing the menstrual cycle. The weakness is that there is no government policy to include this material in the guidance of manasik; provides specialized literature and blessed room facilities.
\end{abstract}

Keywords: Reproductive Health, Hajj, Sexuality, Husband and Wife, Menstruation Management.

\section{Introduction}

\section{Background}

Hajj is the fifth pillar of Islam for Muslims who are able to carry out a certain series of worship at the Baitullah, Masyair, as well as certain places, times and conditions, (Indonesia, 2019), or Hajj, is the fifth pillar of Islam and a once-in-a-lifetime obligation for every Muslim who is able to do it, (Ministry of Religion, 2018).

In performing the hajj pilgrimage, prospective pilgrims have rights that must be fulfilled by the government (Ministry of Religion) as the organizer of the hajj pilgrimage, which includes worship guidance services and health services including reproductive health which includes sexual relations between husband and wife and menstrual management. This is in line with the regulations of the minister of religion that the government is obliged to provide guidance to Hajj pilgrims from before departure, during their journey, while in Saudi Arabia, until their return to Indonesia, which includes guidance on Hajj rituals, travel \& health, (Ministry of Religion, 2018).

With the obligation to provide this guidance, the government must fulfill these obligations to the maximum so that the pilgrims obtain their rights, including the right to guidance and worship services and health including reproductive health. In fulfilling these obligations, there are 
still many obstacles faced by the government in various aspects, so that the implementation of the hajj pilgrimage even though it has good progress every year, still finds obstacles. This resulted in the services provided to the congregation being less than optimal, and when in the holy land there were many problems including the problem of fulfilling reproductive health. If it was not resolved, this problem can interfere with the implementation of the pilgrimage.

How important reproductive health is for the pilgrims, it is appropriate that reproductive health material becomes the material that must be conveyed by the spiritual guide when giving Hajj ritual guidance. However, unfortunately, so far the material on reproductive health has not been maximally delivered and has not become a priority in the implementation of ritual guidance. How and what is the guidance and guidance in carrying out the hajj pilgrimage so far, both by the Indonesian Hajj Advisory Team, the Indonesian Hajj Health Team and the ritual advisors from the Hajj and Umrah Guidance Group in Depok City, it is necessary to conduct research on "Reproductive Health in Hajj (Relationship of Husband and Wife Sexuality and Menstrual Management) ".

Research Purposes

Based on this background, the purpose of this study is to examine in depth how and to what extent the guidance and guidance of the hajj pilgrimage has been carried out and the reproductive health rights of pilgrims have been fulfilled.

\section{Research Methodology}

This research is a qualitative research, with a phenomenological approach. Sociological and Psychological. The main research instrument is the researcher himself (human instrument), which has the function of determining the focus of the research, selecting sources/informants, collecting data, assessing data quality, analyzing data, interpreting data, and making conclusions (Sugiono, 2012). Sources of research data are the words and actions of people who are observed and interviewed as the main data source (primary data), namely respondents who are selected purposively and their numbers are adjusted to the information required. Respondents selected who were competent to provide information consisted of: 4 manasik guides in the Al-Furqon Hajj and Umrah Guidance Group in Depok City, 6 pilgrims in 2017, 2018 and 2019, and the Head of the Haj and Umrah Organizing Section of the Ministry of Religion, Depok City. The rest is supporting data in the form of documents (secondary data). The data was collected using the in-dept interview and document study techniques. While data analysis was carried out using qualitative descriptive techniques. The method used to analyze the data is the inductive method, which departs from specific things then draws general facts, or from very complex data, then analyzes, describes and draws general conclusions. The time for research to writing a report is 8 months, namely MarchOctober 2020.

\section{Research Findings}

\subsection{Reproductive Health In Hajj Manasic Guidance}


In carrying out the pilgrimage, physical health is an important thing that must be considered by the congregation, because Hajj is a physical worship. According to Eka Jusup Singka (2018), the pilgrimage cannot be separated from physical health, because in its implementation it must be done by involving physical movements, so physical health is an important thing that must be prepared. One of the efforts made by the government in fulfilling the health rights of pilgrims including reproductive health is to provide understanding in the perspective of Hajj and health fiqh studies, so that pilgrims can carry out the pilgrimage properly, because the pilgrimage is a form of worship that requires understanding and experience. According to Abdul Choliq (2018) that Indonesian Muslims are still at a weak level of understanding of some of the provisions and procedures for the pilgrimage, so they need a good understanding and stabilization before departure. Meanwhile, according to Achmad Muchaddam Fahham (2015) that briefing/ understanding of the procedures for the pilgrimage is important to be given to ensure the implementation of the pilgrimage according to the conditions and harmonious pilgrimage.

This understanding of the congregation is carried out through the Hajj ritual guidance activities, which are carried out by the Ministry of Religion by involving the community individually and through the Hajj and Umrah Worship Guidance Groups in each district/city. In this case, the government is obliged to provide guidance to the pilgrims from before departure, during their journey, while in Saudi Arabia, until their return to Indonesia. The material provided includes Hajj rituals, travel, and health, (Ministry of Religion, 2018). The process is carried out using the 30 percent theory and 70 percent practice, (Kemenag, 2019).

Manasik guidance has a function as: 1) understanding, which is done to provide understanding to the pilgrims about the pilgrimage; and 2) improvements, which are carried out to provide solutions to various problems faced by the congregation during the pilgrimage, (Sukardi, 2012). According to Antonio Syafi'i (2015), the guidance of Hajj rituals is a process of providing, directing, and providing guidelines for pilgrims to be able to carry out the harmonious, compulsory and procedures of Hajj according to the guidance of the Prophet. Meanwhile, according to Tata Sukayat (2016), Hajj ritual guidance is an explanation and guidance on how to do the Hajj, which is carried out before leaving for the holy land.

In providing this understanding, the implementation of rituals in the Hajj and Umrah AlFurqon Guidance Group, Depok city (research target), refers to two curricular, namely the curriculum from the Ministry of Religion and the curriculum that was compiled by itself, which contains a deeper Hajj fiqh material, (Sainan, 2020). The Hajj jurisprudence material presented includes the pillars and compulsory Hajj. The pillars of Hajj include 6 matters, namely ihram, wuquf, tawaf, sa'i, shaving (tahallul), and peepest. Mandatory hajj includes 5 cases, namely ihram, mabit in muzdalifah, mabit in mina, carrying out 3 jumrahs, and avoiding actions that are prohibited during the pilgrimage (muharramat hajj). Because muharramat hajj is obligatory for hajj, if it is violated, it is obligatory to pay a fine (dam), so that the hajj does not fail. Muharramat haj includes 3 prohibitions: 1 ) specifically for men, there are 5 things, namely not wearing shirts, turban, trousers, skullcaps and shoes; 2) special prohibitions for women, namely: not wearing gloves and covering your face (veil); and 3) prohibitions for men and women include 8 things, namely: wearing parfume, cutting nails, shaving body hair, killing animals, marrying women, marrying and marrying of, having sexual intercourse with the wife, and cutting/pulling plants. This Muharramat Hajj becomes lawful if the pilgrims have performed halal (tahallul) by shaving part of the head hair twice. The first tahallul legalizes some of the Muharramat, and the second tahallul 
makes some of the others legal. If the second tahallul has been carried out, then it is lawful to do all the muharramat hajj, including have sex with the wife. After that, the pilgrims are obliged to continue the unworked hajj practices such as tawaf ifadah, throwing three jumrahs and tawaf wada '.

Reproductive health, including hajj fiqh material which is conveyed through the obligatory hajj material which covers 5 cases, among them are muharramat haji such as having sex with a wife and tawaf for women who are menstruating. Regarding sexual relations with a wife, the material he delivers includes laws relating to wives, time prohibited and allowed, and fines that must be paid if they break them. Regarding menstruation, the material presented includes the law on women who have menstruation to carry out harmonious and obligatory hajj, and how to manage the menstrual cycle during the pilgrimage.

Another reproductive health material presented is maintaining cleanliness (taharah), which discusses menstruation, najis/hadas and tawaf, from the perspective of jurisprudence. Regarding menstruation, the scholars agree that women who menstruate are prohibited from tawaf. However, regarding the impure condition not due to menstruation, the scholars differed. According to the scholars of the Zahiri School, purity from najis, minor hadas, junub, and nifas, is not a legal requirement for tawaf, but the sacredness of menstruation is a valid condition for tawaf. Basically, the hadis from Ayesha: 1) Prophet Muhammad once forbade Ayesha from performing tawaf during menstruation; 2) Prophet Muhammad once ordered Asma 'bint Umais who had just given birth, to take a bath and perform ihram. (H.R. Muslim, Abu Daud, An-Nasai, and Ibn Majah). Meanwhile, the scholars of the Maliki, Shafi'i, and Hanbali Schools agree that people who tawaf must be pure from big hadas, minor hadas, and najis.

To facilitate the absorption of material by the congregation, the delivery of material is carried out through various methods, including: lecture, discussion, private consultation, group consultation, telephone consultation, video viewing, demonstration of tools, and practice. The learning resources used are in the form of turos books/classic books, modules, soft copies/print outs, materials prepared by the supervisor, brochures, flyers/relieflets, CDs, and props. While the volume of learning is carried out as many as 15 meetings with a scheduled time of about 6 months. The delivery of this Hajj jurisprudence material is carried out specifically in one theme and is carried out openly in front of all the congregation. The congregation is given the widest possible opportunity to ask questions about reproductive health issues, and the guides will provide explanations until the congregation really understands, because health services are the right of the pilgrims. According to the Ministry of Health (2016), prospective pilgrims are required to receive health istitho'ah (eligibility) guidance.

Through the manasik guidance model as described, the Al-Furqon Hajj and Umrah Worship Guidance Group in Depok City was able to provide a good understanding to the congregation about the procedures for the hajj pilgrimage, including an understanding of maintaining reproductive health including sexual relations between husband and wife and menstrual management. This good understanding is generally owned by young pilgrims who have higher education and extensive knowledge. Meanwhile, for the elderly congregation, there are still many who do not understand even though they have been given guidance. Therefore, when in the holy land, continuous guidance is carried out once a week, which is carried out in mosques and hotel hallways, through group and private guidance (Sainan and Bariyah, 2020). 
Meanwhile, understanding reproductive health from a health/medical perspective is carried out in collaboration with puskesmas doctors and the Indonesian Hajj Health Team, by providing materials such as maintaining genital hygiene. According to Liva Wijaya (2016), a woman's genitals (vagina) have an important role as a way out of blood during menstruation, a tool for sexual intercourse, a temporary storage place for sperm to enter the uterus, and a birth canal during normal delivery. If the vaginal function is not kept clean, it will easily become infected by bacteria, such as "mold" (candidiasis), which results in itching and even pain. Meanwhile, in men, unclean genitals make "smegma" accumulate. According to Muhammad Zaiem (2016), smegma is formed from dead skin cells, if it is cleaned frequently, it will be clear in color, and if left untreated it can accumulate mixed with sweat and oil glands in the skin, making it look like cheese. This causes adhesion between the "prepuce" and the "glans penis", and results in the penis feeling sore when erect occurs and can interfere with sexual intercourse.

Included in maintaining the cleanliness of the genitals is shaving hair on the genitals, because it can be a nesting place for germs. As the Rasulullah hadis:

Meaning: "Rasulullah saw has set a time for us to shave our mustaches, cut nails, remove armpit hair, and shave pubic hair, that is, so that we don't leave it for more than 40 nights". (H. R. Muslim, Abu Dawud, At-Tirmidziy, An-Nasa'iy, and Ibn Majah)

Another reproductive health material that was also presented was maintaining the health of the uterus. According to Sri Pujianto (2014), the uterus is the main reproductive tool which is very vital, has a function as a place: 1) the gamete channel (Spermatozoa) when fertilization or ejaculation occurs; 2 ) holding the fertilized egg (ovum) from the sperm to grow into a fetus; 3 ) implantation at the onset of pregnancy; 4) fetal growth and development; 5) to protect and provide nutrition for the fetus; and 6) pushing the fetus and placenta out during delivery.

This description illustrates that Islam also pays great attention to reproductive health. According to Ahmad Edwar (2019), reproductive health gets a foothold from the teachings of fiqh which are quite strong (legitimate). The concept of fiqh regarding the health of the reproductive organs is to emphasize the importance of protecting the reproductive organs from various diseases, both physical, biological and mental diseases. In addition, fiqh also provides instructions, guidance, guidance, knowledge and values on how a Muslim should behave and make decisions regarding the health of his reproductive organs. The goal is to be able to carry out reproductive processes in a healthy manner, so that healthy future generations will be born.

\subsection{Reproductive Health And The Problems In Haji Worship}

\section{Sexuality and Its Problems}

Sexuality is a basic need of every human being as well as other needs such as eating, drinking, etc. If this sexual need is not gotten, it can have a negative impact on physical and psychological health. Sexologist Zoya Amirin (2012) states that unfulfilled sexual needs can have physical and psychological impacts, such as hot bodies, dizziness, chills, irritability, irritability, anxiety, unhappiness, cynicism, negative behavior such as cursing and screaming. For some productive age pilgrims, sexuality is a basic need that must be fulfilled, because at a productive age a person's sexual desire is very strong. However, this sexual desire can be managed well, if the congregation is able to focus their hearts and minds on worship, remembrance, praying, reciting 
the Qur'an, praying sunnah, fasting, i'tikaf in the mosque, etc. How long they are able to manage it is not guaranteed, considering that the pilgrimage takes longer than one month.

According to H. Sainan (2020), the ability of the congregation to manage their sexual needs varies depending on their perspective and how to react to them. For pilgrims who have the view that sexual need is human nature and if it is a form of worship, then when they are in the holy land they will try to control it during forbidden times, but will instead try to fulfill it outside of that time. But for those who intend to focus on worship only, they tend to control their sexual desires. According to Suparno (2006), there are several ways to manage sexual needs, namely: building self-awareness and gratitude, placing sexuality in the right sense; build deep relationships with yourself, God, and others; increase prayer; develop love, intimacy, joy; affection; and true to the main commitments. According to H. Ahmad Sya'bani (2020), sexual problems faced by congregations in the holy land include:

- It is difficult to restrain sexual desires, because consuming a lot of meat increases libido, and because of the condition of the congregation who is always making out with a partner.

- It is difficult to find a place for sexual intercourse when in Makkah, due to the division of rooms that do not prioritize the interests of productive age congregations.

- There are no blessed rooms as a place to execute sexual needs.

- It often happens that the congregation goes missing for about 24 hours, looking for a hotel to execute their sexual needs, and this is inconvenient for the group leader because he does not say goodbye.

\section{Menstruation and Its Problems}

Menstruation is a problem that can interfere with the smooth running of the pilgrimage, especially for female pilgrims. Therefore they need to have a good understanding of menstruation, from the aspects of jurisprudence and health. Menstruation is the process of releasing the lining of the uterine or endometrial wall accompanied by bleeding, which occurs every month, due to the absence of embryo implantation (Endang Purwoastuti \& Elisabet Siwi Walyani, 2015). According to Ernawati Sinaga et al. (2016), menstruation is bleeding from the uterus that begins about 14 days after ovulation, due to the release of the endometrial lining because there is no fertilization of the egg by sperm. For normal women, menstruation occurs every month during the reproductive period, starting at puberty (menarche) and ending at menopause, except during pregnancy.

Menstruation is said to be normal if the cycle is not less than 21 days and not more than 35 days (Sarwono, 2011). The menstrual cycle is the distance between the start date of the last period and the start of the next period. Meanwhile, the length of menstruation is the length of time the blood comes out during menstruation, under normal conditions it lasts 4-8 days (Sarwono, 2011). The menstrual cycle will be abnormal if there are health and emotional problems, which sometimes causes frustration for sufferers (Sarwono, 2011). Abnormal menstrual cycles occur outside the 21-35 day interval, for example: menstruation too often or infrequently for 3 consecutive months, cycles $<21$ days or $>35$ days, or no menstruation for 3 months, (A.Baziad, 2008).

Menstruation is said to be normal if the cycle is not less than 21 days and not more than 35 days (Sarwono, 2011). The menstrual cycle is the distance between the start date of the last period and the start of the next period. Meanwhile, the length of menstruation is the length of time the blood comes out during menstruation (medscape), or the distance from the first day of 
menstruation until the bleeding stops, under normal conditions it lasts 4-8 days (Sarwono, 2011). The menstrual cycle will be abnormal if there are health and emotional problems, which sometimes causes frustration for sufferers (Sarwono, 2011). Abnormal menstrual cycles that occur outside the 21-35 day interval, for example: menstruation too often or infrequently for 3 consecutive months (polimenorrhea), cycles of less than 21 days or more than 35 days (oligomenorrhea), or no menstruation for 3 consecutive months (amenorrhea), (A.Baziad, 2008).

Irregular menstrual cycles are a problem for women when carrying out the pilgrimage, because it is difficult to predict when menstruation will come out, so that menstruation can come out at any time even in the middle of worship, for example tawaf. In fact, from the aspect of fiqh, menstruating women are prohibited from tawaf. Regarding this menstrual cycle, many questions are raised during the training of manasik, including:

- How to manage the menstrual cycle, so as not to come on a period during the haj pilgrimage

- Are there any side effects for uterine health, by promoting and rewinding the menstrual cycle

- How is the law from a fiqh point of view, to advance and reverse the menstrual cycle

- What is the law, if you are in tawaf you are obliged to suddenly have menstrual blood

- What is the law if you are worshiping suddenly vaginal discharge.

- How to maintain the cleanliness and health of the uterus after menstruation

- How is the law when you are in worship, suddenly the remaining semen comes out of the vagina

The emergence of these questions indicates that female pilgrims are worried about the obstacles that could abort their Hajj, because the menstrual discharge during the Hajj pilgrimage. According to Arofah and Haidir (2020), the worries of this female congregation are sometimes excessive, even some are acute (stressed), even though a stressed body is difficult to manage menstruation. According to Kapoor G. Nagma S, et al (2015), disturbances in the menstrual cycle such as longer menstrual duration and cycle irregularities, one of the reasons is stress.

Medically, women whose menstrual cycles are normal can be managed by taking medicines according to a doctor's prescription, by calculating the date at which their menstrual habits will appear. Meanwhile, psychologically, menstruation can be managed by managing your heart and mind so you don't get stressed easily. According to Nasution Is (2010), stress can stimulate the Hypothalamus-Pituitary-Adrenalcortex, resulting in irregularities. Many cases of female congregation have taken medication according to a doctor's prescription, but menstrual blood continues.

\section{Weak Policies In Overcoming Health Problems}

Until now, the government has not been able to provide maximum management services by providing all the facilities needed, such as:

- There is no policy to include reproductive health material as mandatory material in medical guidance, in the form of regulations as a legal umbrella.

- There is no literature available on maintaining reproductive health for productive age pilgrims, including sexual relations between husband and wife and menstrual management.

- The absence of barokah room facilities as a means of executing husband and wife sexual needs in the holy land. 


\section{Closing}

\subsection{Conclusion}

The research entitled "Fulfillment of the Reproductive Health Rights of Productive Age Hajj Pilgrims" shows that in general the rights of pilgrims have been fulfilled, especially in terms of knowledge and understanding of Reproductive Health obtained through manasik guidance by the Hajj and Umroh Al-Furqan Guidance Group for Depok City and by the Indonesian Hajj Health Team through health examinations and guidance. The understanding of this congregation includes: the problem of sexual relations between husband and wife during the pilgrimage, namely when the time is allowed and prohibited from doing so in terms of fiqh, how to maintain the health of reproductive organs such as genitals and uterus; and how to manage the menstrual cycle for female pilgrims. The deficiencies found from the results of this study are:

- There is no policy (regulation) to include reproductive health material as mandatory material in medical guidance

- There is no literature on reproductive health as a guide for pilgrims and guides

- The absence of barokah room facilities as a place to execute husband and wife sexual needs

\subsection{Recommendation}

Considering that there are still problems in fulfilling the rights to reproductive health of Hajj pilgrims, the Ministry of Religious Affairs should improve its services through improved management of rituals, such as: include reproductive health material as mandatory material; provide specialized literature on reproductive health as a guide for guides and pilgrims; increasing health development through special reproductive health guidance programs; and improving services for pilgrims through the provision of baraka room facilities of at least 2-3 rooms at each hotel / inn.

\section{Thank-You Note}

This research went well because of the help of many parties. Therefore I, as the author, would like to thank: Head of the Center for Research and Development, Guidance for Religious Communities and Religious Services who have provided guidance and direction, fellow researchers who have helped in the discussion and refinement of research designs and instruments; field assistants, respondents and resource persons who have helped smooth data collection

\section{References}

[1] Ahmad, E. (2019) Pengaruh Pembelajaran Ilmu Fiqh Dalam Perspektif Kesehatan Reproduks. Jurnal Pendidikan Agama Islam Vol. 6, No.2 (Juli-Desember) 2019

[2] Amirin, Z. (2012) in his article entitled "Kalau Kebutuhan Seks Tak Terpenuhi". Available in https://ifestyle.kompas.com/read/2012/08/30/19151631/Kalau.Need,Sex,Tak,Fulfilled. accessed on 5 April 2020.

[3] Antonio Syafii, M. (2015) “Buku Cerdas Haji dan Umrah”. South Jakarta 
[4] Arofah and Haidir (2020) interviewed 2018 pilgrims, on Thursday 12 March 2020, in the hall of the AlFurqon Hajj and Umrah Guidance Group

[5] Baziad, A. (2008) “Endocrinology of Gynecology”. Jakarta: Media Aesculapius, Faculty of Medicine, University of Indonesia. Edition III.

[6] Choliq, A. (2018) Esensi Program Bimbel Manasik Haji Upaya Pemberdayaan Masyarakat. Jurnal AtTaqaddum, Volume 10, Nomor 1, Juli 2018

[7] Hanafiah, M.J., (2009) "Haid dan Siklusnya". Jakarta: P.T. Bina Pustaka

Indonesia (2019) Law Number 8 of 2019 Concerning the Implementation of Hajj and Umrah Worship

[8] IS, N. (2010) "Hubungan Stres dengan Siklus Menstruasi yang Tidak Teratur pada Mahasiswi Fakultas

Kedokteran USU Angkatan 2007”. Medan: University of North Sumatera. Andalas Health Journal. 2017, 6

(2)

[9] Jusup Sinka, E. (2018) in his statement in Detik Com Media, July 72018 entitled "So that you don't get sick during the Hajj, pilgrims must prepare for it". Available at https://health.detik.com/berita-detikhealth/d4102983/agar-tak-sakit-saat-ibadah-haji-jamaah-harus-persentuk-ini, accessed on 5 May 2020.

[10] Kumalasari, I., and Andhyantoro, I, (2012) "Kesehatan Reproduksi: Untuk Mahasiswa Kebidanan dan Keperawatan”. Jakarta: Selemba Medika.

[11] List of Manasik Materials at Hajj and Umrah Guidance Group Al-Furqon in 2019

[12] Ministry of Religion (2018) Regulation of the Minister of Religion of the Republic of Indonesia Number 13 of 2018 concerning the Implementation of Regular Hajj.

[13] Ministry of Religion (2019) Decree of the Director General of Hajj and Umrah Implementation Number 146 of 2019 concerning the Implementation of Hajj Manuals

[14] Ministry of Health (2016) Minister of Health Regulation Number 15 of 2016 concerning Istitho'ah Health of Hajj Pilgrims

[15] Muchaddam Fahham, A. (2015) Penyelenggaraan Ibadah Haji: Masalah Dan Penanganannya. Jurnal Kajian: Menjembatani Teori dan Persoalan Masyarakat dalam Perumusan Kebijakan. Vol. 20 No. 3 September 2015

[16] Nagma S, Kapoor G, Bharti R, Batra A, Batra A, Aggarwal A, et al. (2015) To Evaluate the Effect of Perceived Stress on Menstrual Function. JCDR: 9 (3): 1-3.

[17] Pujianto, S. (2014). "Menjelajah Dunia Biologi. Surakarta": Tiga Serangkai

[18] Sainan and Bariyah (2020) interviewed the head of the Al-Furqon Hajj and Umrah Guidance Group, Depok, on Wednesday 11 March 2020, in the his living room office.

[19] Sarwono. S.W. (2011) “Psikologi Remaja”. Jakarta: Raja Grafindo Persada

[20] Sinaga, E., et al. (2017) Manajemen Kesehatan Menstruasi. Jakarta: IWWASH Global One National University

[21] Sugiyono (2012) Metode Penelitian Kuantitatif, Kualitatif, dan $R \&$ D. Bandung: Alfabeta. 17th printing.

[22] Sukayat, T (2016) “Manajemen Haji, Umrah dan Wisata Agama”. Bandung: Simbiosa Rekatama Media. [23] Suparno, P. (2006) "Spiritualitas dan Seksualitas dalam Hidup Membiara, Rohani Menjadi Semakin Insani: Menopang Impian Terpendam. Yogyakarta: Kanisius.

[24] Sya'bani (2020) interview with 2019 pilgrims, on Thursday 12 March 2020, in the hall of the Hajj and Umroh Al-Furqon Guidance Group

[25] Wijaya, L. (2016) in his article entitled "Risk of Infection Due to Not Maintaining the Health of Intimate Organs". Available at https://mommiesdaily.com/2016/10/23/risiko-inf-akibat-tidak-menjaga-kesehatnorgan-intim/, accessed on 6 April 2020.

[26] Zaiem, M. (2016) in his article entitled "Alat Kelamin Pria tidak Bersih? Ini Sederet Akibatnya". Available at https://republika.co.id/berita/o4gozk328/alat-kelamin-pria-tidak-bBersih-ini-sederet-akibatnya. accessed on 6 April 2020. 